Article

\title{
Impacts of Reverse Global Value Chain (GVC) Factors on Global Trade and Energy Market
}

\author{
Byeongho Lim ${ }^{1} \mathbb{D}$, Jeongho Yoo ${ }^{2}$, Kyoungseo Hong ${ }^{3}$ and Inkyo Cheong ${ }^{4, *}$ \\ 1 Korea Maritime Institute, Pusan 4911, Korea; bhlim@kmi.re.kr \\ 2 Division of International Commerce, Pukyong National University, Pusan 48434, Korea; jhyoo@pknu.ac.kr \\ 3 Program in International Relations, New York University, New York, NY 10012, USA; kh2861@nyu.edu \\ 4 Department of International Trade, Inha University, Incheon 22212, Korea \\ * Correspondence: inkyo@inha.ac.kr; Tel.: +82-10-9571-6288
}

Citation: Lim, B.; Yoo, J.; Hong, K.; Cheong, I. Impacts of Reverse Global Value Chain (GVC) Factors on Global Trade and Energy Market. Energies 2021, 14, 3417. https://doi.org/ $10.3390 /$ en14123417

Academic Editors:

Svetlana Ikonnikova and

Ignacio Mauleón

Received: 15 April 2021

Accepted: 8 June 2021

Published: 9 June 2021

Publisher's Note: MDPI stays neutral with regard to jurisdictional claims in published maps and institutional affiliations.

Copyright: (c) 2021 by the authors. Licensee MDPI, Basel, Switzerland. This article is an open access article distributed under the terms and conditions of the Creative Commons Attribution (CC BY) license (https:// creativecommons.org/licenses/by/ $4.0 /)$.

\begin{abstract}
Since the outbreak of COVID-19 and the American decoupling policy, the global value chains (GVCs) have been switched to regional GVCs, and, in the worst case, are subject to a potential alteration of reversing the GVCs, ultimately entailing a severe impact on international trade and the global energy market. This paper applies a quantitative approach using a computational general equilibrium (CGE) model to estimate the effects of the reverse GVC factors on the global economy, trade, and energy market. These reverse GVC factors will decrease the global GDP, and such effect will bring a greater influence on both China as well as the United States, which is pursuing decoupling. The increased trade costs due to these factors will reduce the GVC indices, mostly in ASEAN by $0.2 \sim 1.15 \%$, followed by Korea, Japan and China. Surprisingly, the GVC index in the United States is expected to be strengthened due to the enhanced GVC with its allies such as Canada and Mexico. In China, the use of oil, gas and petroleum is expected to decrease by around $10 \%$, and similar effects are expected in Korea and the EU. Among the world's major energy producers, it is estimated that the US will reduce energy exports by 16-62\% depending on the energy source, and the Middle East and Russia will significantly reduce their gas exports. The global energy market is shrinking, but in particular, the international gas market is expected to decrease by $27.3 \sim 38.6 \%$.
\end{abstract}

Keywords: global value chain (GVC); reverse GVC factors; decoupling; COVID-19; global energy market

\section{Introduction}

In the last 30 years, the global economy has experienced the Goldilocks growth twice: in the mid-1990s due to the launch of the World Trade Organization (WTO), and in 2003 2007 after the dotcom bubble burst in the early 2000s to the 2008 global financial crisis (GFC). Subsequently, there has not been any Goldilocks era and the global economy in the 2010s is relatively weaker than that before. During the Goldilocks era, the global value chain (GVC) expanded fast, and the demand for imports and international trade subsequently increased due to income growth in resource-rich countries. Due to the increase in energy demands followed by the high growth of the global economy, the global energy market boomed.

Over the long-term, international trade has been coupled with economic growth. After World War II, despite intermittent crises, the global economy was well managed. Since the new millennium, however, numerous global crises have shocked the GVC, which had been expanding across borders pursuing international production process optimization. The ongoing COVID-19 pandemic switched weakened GVC to regional GVC, and even to reverse GVC, with severe impact on international trade and the global energy market.

International trade and GVC will be largely influenced or even controlled by the aftereffects of many reverse-GVC factors such as the COVID-19 pandemic, global protectionism, the U.S.-China conflict and decoupling, rapid development of digital technology, and 
others [1-3]. The COVID-19 pandemic has accelerated digitization, expedited reshoring, and subsequently encouraged the phenomenon of reverse-GVC [4,5]. Although vaccination and herd immunity are becoming potential game changers, that does not mean that the global economy will revert to its pre-pandemic state. Nature [6] published an article entitled, "Five reasons why COVID herd immunity is probably impossible". Since the COVID-19 shock has been immense and can happen again anytime, travel restrictions or import controls of many countries are likely to be retained for a long time.

The COVID-19 blame game on China, which has earned credibility based on the logic of promoting decoupling associated with various criticisms of the behavior of the Chinese Communist Party and its political system, has led to another conflict between the United States and China. This can further deteriorate the already weak global economy and value chains, which can ultimately bring a negative impact on the global energy market. As the functioning of GVCs is exposed to the fragility of high interdependencies between firms and suppliers across the globe, the U.S. decoupling policies will even more aggravate the reverse-GVC factors. Several studies have been conducted on the impact of each factor on global trade environment. For example, there are several studies on the impact on COVID-19 [7,8] and on the recent GVC change [9-11]. However, if these factors are combined simultaneously, or if the influences between factors give a mutual synergy, the total impact will be much greater than the sum of the effects of single factors. Unfortunately, no studies have been conducted on these complex effects. With the mutual interaction of these reverse-GVC factors, the GVC may suffer further degradation, with a continuous negative impact on international trade and the global energy market. In general, negative factors are highly dominant for the global energy market today. Much literature has descriptively suggested that GVC will be subject to reduction or play out in other forms. However, not to mention that not many studies have empirically analyzed how the global crises will affect the international trade, little research has examined the impact on the global energy market. This paper estimates the effects of the global crises on global trade and energy market with a quantitative approach and will draw policy implications.

\section{Literature Review on Reverse-GVC, COVID-19, Reshoring}

The global economy is facing several factors that promote reverse GVC. Understanding these is important in designing research. As mentioned earlier, these factors may have their own effects, but they are related to each other, and negative effects for GVC may be magnified. Previous studies have not analyzed these linkages, but here we will present the interrelated matters while reviewing previous studies on individual factors.

\subsection{Issues of $G V C$}

The global economy is formulated through a complex set of GVCs [12], which provide an opportunity to improve global GDP, especially the national income of developing countries [13-15]. Corporations can obtain more advantages than risks and challenges it entails from participating in GVCs [16,17]. Such advantages include an efficient connection between input and output [18], acquisition of advanced technology [19], an increase in the variety of inputs [20] and social and economic upgrade [21]. GVCs have been a core part of international trade, global GDP and employment [22]. GVC relates to the 'spoke corporation-trade of parts-hub corporation', and more than two-thirds of the international trade is trade through GVCs. GVC hubs are primarily operated by multinational corporations (MNCs), and the GVC trade of MNCs occupy about $80 \%$ of the global trade [23].

The growth rate of trade had exceeded that of economic growth in the past, yet, after the GFC, the opposite happened. Recently, energy demand and international oil prices have also tended to be sluggish, along with the trade volume and GVC. From 2001 to 2016, the country that held up the Commodities Super-Cycle (CSC), implying the long-term trend of an increase in price for over 20 years, was China. McKinsey [24] expected that China will occupy more than $40 \%$ of the world's energy consumption, and Goldman Sachs [25] 
anticipated another CSC in the middle of the pandemic. Nevertheless, McKinsey [26] forecasts that the global oil demand will take 2 4 years to return to its pre-COVID-19 level, although it will increase with economic recovery in 2021.

Although the original GVC was constructed on the premise of the 'business as usual' circumstance, opportunity costs and risks have increased followed by the expansion of GVCs. GVCs can always experience natural disasters, wars, terror, or others [27-30].

A participant in GVCs can earn benefits, but such benefits are not automatically guaranteed. Maximizing the benefits arising from participating in GVCs requires good institutions and policies, and strategic cooperation and vision between agents of various GVCs must be based as premises [31]. The Doha Development Agenda (DDA), which began in 2001, has been cancelled, and the WTO suffers greatly weakened capacity to establish new global trade rules to deal with the changing global trade environment [32] except the Trade Facilitation Agreement in 2014, along with a reduced role in setting even digital trade rules [33]. It is clear that reverse-GVC factors prevail in global economy.

\subsection{COVID-19, Decoupling, and Reverse-GVC}

COVID-19 has been a critical component in severely damaging the already deteriorated GVCs. The countless fatalities, border closures, lockdowns, and banning of face-to-face activities are some of its examples. Some argued that COVID-19 must be understood in the context of national security [34]. The United States has raised the China blame game and subsequently used it in the context of the prism of decoupling. The COVID-19 responsibility argument raised by the United States against China has led to the solidarity of allies including the United Kingdom, the EU, Australia, Canada and Japan. The US is pursuing decoupling with China through solidarity with allies by establishing various groupings such as the Quad-4 (the United States, Japan, Australia, India) and Democratic-10 (the Quad-4, Canada, France, Germany, Italy, Korea, UK).

Further, its China policies have been strengthened by the Biden Administration. The United States considers the 'Made in China 2025' policy as 'military-civil fusion' strategy [35], and has been trying to contain China's growth in multi-dimensions, including imposing tariffs, export control on private companies such Huawei, strengthening investment screening, and instigating rules on individual corporations. In addition, the United States has been imposing direct trade sanctions on more than 300 Chinese companies as of the end of 2020, while promoting reshoring and decoupling. The Department of State [35] concludes that "China is a challenge because of its conduct". In response to this, China introduced the 'dual circulation' policy in 2020, and President Xi criticized the United States for pursuing 'selective multilateralism' by excluding China on the global stage in the 2021 World Economic Forum.

Since the outbreak of COVID-19, advanced countries including the United States, the European Union, and Japan, have been inducing their companies in China to return to induce homelands. Due to the pandemic, many corporations are in the process of modifying their sourcing strategies to place further emphasis on safety of GVCs $[4,36,37]$. Reshoring is not confined to GVC-intensive industries of advanced technology. Digitization and platformization of supply chains will accelerate, and production processes will also go through rebundling of production stages [12].

Leaving China, which is both 'the world's factory' and 'the world's market', is not an easy decision for huge opportunity costs. Morgan Stanley anticipates that China's private consumption will be $\$ 12.7$ trillion in 2030. Germany has been hesitating to leave China due to its interests in automobiles and machine industry [38]. However, as the international trade order is shaking, it is difficult to sustain the original GVC which accentuates the unit cost of production [39]. Although decoupling incurs immense damage on the United States itself, national security concerns, both political and in the public arena, have made decoupling unavoidable [34]. The Biden administration has been continuing the Trump administration's reshoring policies [40,41]. 
Although much literature has tried to estimate the effects of COVID-19, little research has focused on estimating the impact of decoupling in specific. In the first half of 2020, international organizations such as the WTO, the IMF, and more, had forecast a huge shock from the pandemic. In "World Economic Outlook", the IMF [42] had expected that the global economy would experience an enormous shock, as implied in its subtitle, "The Great Lockdown". It had been anticipated that the global economy would face a greater shock than that of the 2008-9 GFC, with an estimated decrease of 3\%. The WTO [43] had originally anticipated that the 2020 global trade volume would be reduced by $13 \sim 32 \%$, but later corrected this to $-9 \%$, European Commission [44] estimated that the global trade will be reduced by $9.7 \%$, with an emphasis on the increase in trade costs. McKinsey [45] estimated that the global GDP will decrease by $3 \sim 8 \%$, and the global trade will recover to the level of the fourth quarter in 2019 over 15 48 months; the trade loss was estimated to be $8 \sim 49 \%$ of the global trade in 2019 .

Steinbock [46] suggests that the U.S.-China conflict can lead to decoupling, and Goulard [47] claims that the conflict led to an immense loss for the EU. Many studies suggest that the U.S.-China tariff war has hurt both of their economies [48-50]. Mao \& Görg [49] estimate the ripple effect of both countries' increase in tariffs through inputoutput tables, and find a loss of $\$ 500 \sim 600$ million for both countries. Itakura [50] estimated that the GDP loss of the United States and China will be $-1.41 \%$ and $-1.35 \%$, respectively. Yet, Hanson [51] and Hass and Denmark [52] claimed that the United States will experience a bigger loss than China. The U.S. Chamber of Commerce [53] anticipated that the United States will face an annual loss of $\$ 190$ billion with its $25 \%$ tariffs on its imports from China.

Nevertheless, an empirical estimation of the impact of COVID-19 and decoupling on reverse-GVC has not yet been conducted, nor any study on how it will affect the global energy market. The reverse-GVC not only impacts the demand for global energy demand but also will decrease the energy demand needed for global transport.

\subsection{Energy Demand}

Many studies have empirically analyzed the positive relationship of exports or trade and energy consumption or demand [54-60]. Palamalai et al. [58] empirically suggest that international trade increases energy demand and economic activities. This is supported by Arif et al. [60].

Narayan and Smyth [55] and Chaudhry et al. [61] confirm a positive relationship between trade and energy demand through studying the countries in the Middle East and Pakistan. Dedeoğlu \& Kaya [62] estimated a long-term interrelationship between GDP, trade, and energy consumption: a 1\% increase in GDP, exports, and imports will increase energy demand by $0.32 \%, 0.21 \%$, and $0.16 \%$, respectively. Shahbaz et al. [57] corroborated a bi-directional causality between trade and energy consumption by studying 91 countries.

Although China has been promoting the dual circulation strategy, the nation's energy demand may eventually decrease if the U.S. decoupling intensifies and the CSC further weakens. China consumes $24 \%$ of the world's total energy demand according the statistics of the WorldoMeters [63]. Moreover, the expansion of GVC was sluggish before and after 2012 [23,64]. In contrast, a future expansion of the reverse-GVC will render any energy super-cycle very unlikely.

\section{Method of Analysis and Data}

\subsection{Past Cases on GVC Shocks}

Since 2000, the GVC has suffered several devastating disturbances. The 2008-9 GFC, the earthquake in Japan in 2011, and the Chao Phraya river flood in Thailand in 2011 re-emphasized the importance of the GVC resilience. In the beginning of 2021, the unprecedented Texas cold snap in the United States led to a huge impact on the GVCs of the major industries, including semiconductors and automobiles.

However, none of these devastating disturbances is any match for the damage incurred to GVC by the COVID-19 pandemic. Furthermore, this global public health crisis has largely 
degraded other factors associated with reverse-GVC. Although the GFC reduced the global trade volume by more than $10 \%$, it recovered rapidly. Cattaneo et al. [22] claimed that the GVC resilience contributed in the context of "rebalancing". The recovery efforts by the United States, which had been the origin of the crisis, and the 'simultaneous economic stimulus' packages of the G20 members played crucial roles. Despite the efforts to prevent the GVC deterioration, the GVC activities were sluggish for 6 years from 2012. Nevertheless, a subtle recovery commenced in 2017; thus, Li et al. [65] viewed that the GVC expansion may be of expectation.

However, UNCTAD [23] analysis of the correlation between international trade flows and global GDP found that the GVC has subsequently become dormant. Moreover, due to the U.S.-China trade war and COVID-19, the reverse-GVC may have been intensified. No study has empirically analyzed the impact of these factors on global GVC activities. The shock exerted by the pandemic on the GVC is much more substantial than that from the GFC [45,66], and the world's production system has fallen into "a perfect storm" [23]. Although some countries, including the United States, have begun recovering from the pandemic coming into 2021, and others such as China had already returned to positive GDP growth in 2020, the COVID-19 shock is expected to stay for a long period of time.

\subsection{Research Design}

Figure 1 diagrammatically presents the main research design of this paper. To analyze the ripple effect of the reverse-GVC factors such as the U.S.-China decoupling and COVID-19 on the global trade and energy demand, this paper uses the computational general equilibrium (CGE) model. The most widely used CGE model is the GTAP model [67]. CGE models are a popular tool in estimating the impact of policy changes, as explained in Dixon et al. [68] in details. Apart from the simulation model, setting up simulation scenarios and constructing the database are critical parts of the research.

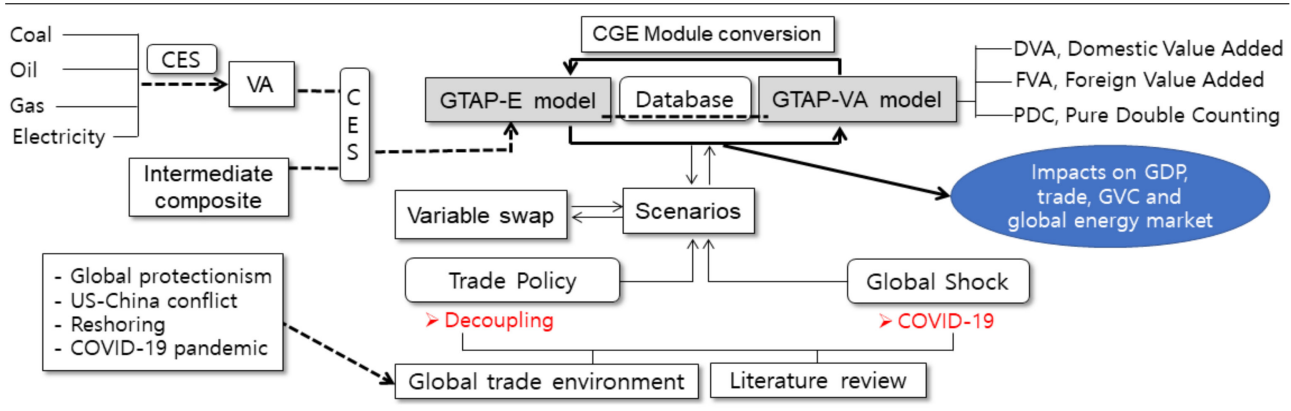

Figure 1. Overview of research approach.

This paper uses the GTAP-E (Energy) model and the GTAP-VA (Value-Added) model to estimate the ripple effect of the reverse-GVC factors. The former is used to estimate the effects on the global energy market and the latter to estimate the impact on GVCs. Although it is possible to integrate the two models, the paper uses each separately by one considering the complexity of the combined model. To estimate the effects of the GVC, the value-added (VA) included in the home country's exports should be calculated through domestic VA (DVA), foreign value-added (FVA), and pure double counted terms (PDC). Through simulations by each study scenario, the research can estimate the effects on each country's GDP, trade, GVC, and the global energy market.

\subsection{Brief Description of the CGE Models}

The GTAP-E model includes the energy-primary factor substitution as a module into the GTAP model, which offers flexibility in dealing with the input of the necessary energy for production. Due to the space limitation of this paper, detailed information on the GTAPE model can be found in Burniaux and Truong [69], and Truong, Kemfert and Burniaux [70]. As suggested in Figure 2, the production system of the GTAP-E model comprises 6 nests 
that are necessary to estimate the effects on demands of gas, oil, and petroleum that are non-coal energy sources.

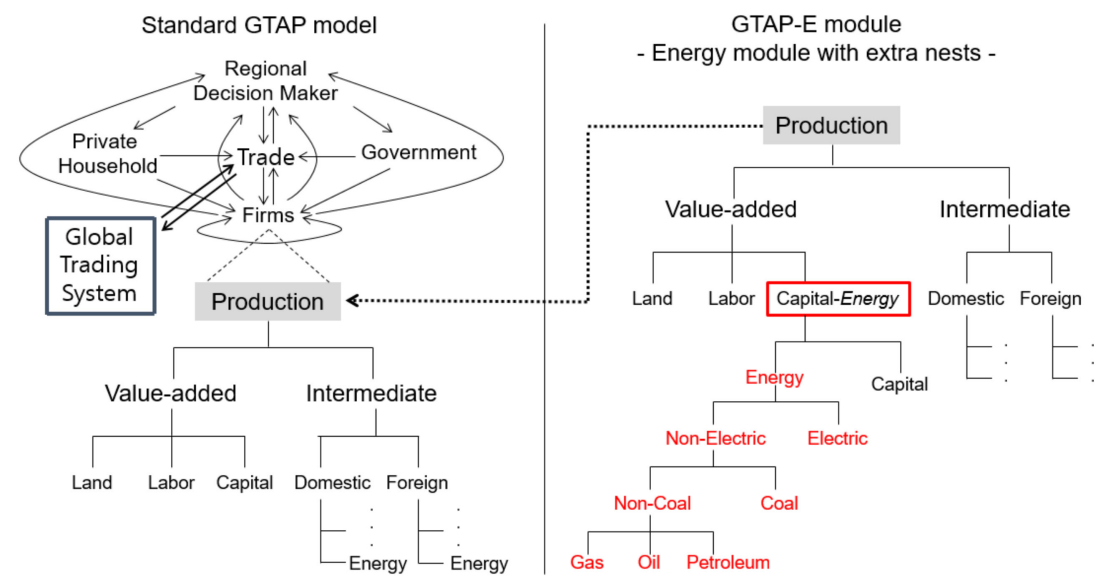

Figure 2. GTAP-E model description.

The GTAP-VA model includes a module that can divide the VA of exports as a part of the GTAP model. This was developed to overcome the model limitation that prevented any elucidation of the GVC through traditional Gross Trade Flows. Analyzing more precisely the GVCs between countries requires a method for calculating VA trade flows, as suggested in Koopman [71], Wang et al. [72], UNESCAP [73] and more.

To simply explain using Antimiani et al. [74], let us look at trade between Countries r, $\mathrm{s}$, and $\mathrm{w}$ in Figure 3. In terms of the Gross Trade Flows, Country $r$ has conducted trade worth of 11 (exports 1 and imports 10), and Countries s and w, each 5 and 14, respectively; then, the total gross product become 15. However, when calculated as suggested on the right through the VA Trade Flows, Country $r$ is a net importer, and its amount of imports becomes 9 (the 1 being consumed domestically) in terms of the VA Trade Flows, then the total product of the three countries becomes 10 . In other words, while the traditionally calculated product of 15 experiences the double-counting of 5, which is one-third of the original value, the analysis of VA has this double-counted value removed. The model of VA Trade Flows will reveal the difference between the total volume of exports and the VA trade exports. The GTAP-VA model allows this operation by broadly dividing the total exports into domestic (DVA), foreign (FVA), double-counted (PDC) factors, and analyzing where such factors are consumed [75]. This methodology facilitates a comparative analysis of the effects of policy-based GVC. By removing the aforementioned double counting included in the total exports, the method more accurately explains the trade relation [76,77].

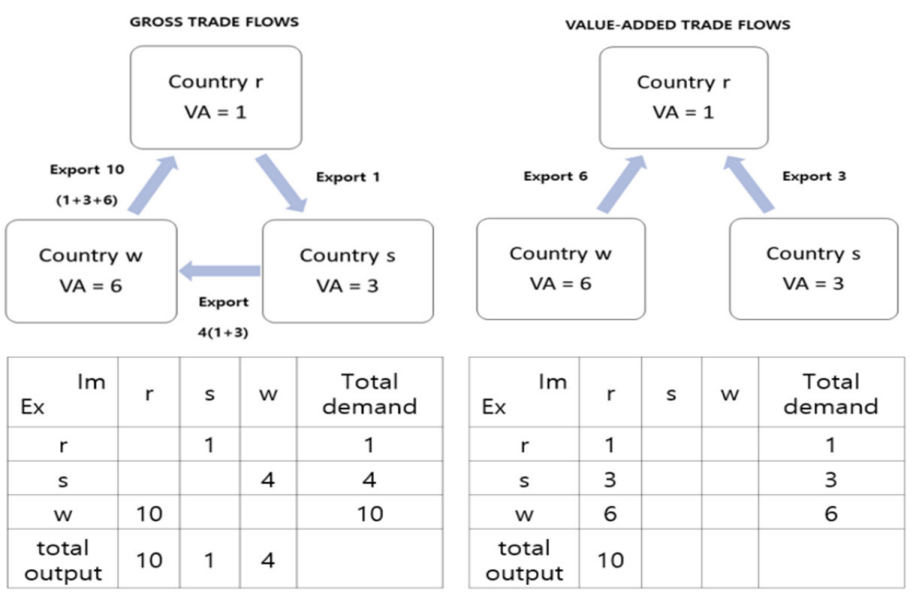

Figure 3. Value-Added (VA) Trade Flows description. 


\subsection{Database}

The GTAP-E database, which has been specialized for the GTAP-E model, is used, and the types of energy are differentiated into coal, oil, gas, petroleum, and electricity. The GTAP-E DB v10 was launched in February 2020, and its database includes 141 countries and 65 industries, which in the present research have been aggregated into seven regions and eight industries (Table 1). The seven regions are the United States, the European Union, Japan, Korea, ANZ (Australia, New Zealand), CM (Canada, Mexico), Central America, ASEAN, Middle East, China, Russia, Iran, and Rest of World (ROW). The eight industries are Agriculture, Coal, Oil, Gas, Petroleum, Electricity, Energy intensive industries, and Other industries and services.

Table 1. GTAP-E DB aggregation.

\begin{tabular}{|c|c|c|}
\hline Country & & Industry \\
\hline \multirow{2}{*}{$\begin{array}{l}\text { USA, EU, Japan, Korea, ANZ(Australia, } \\
\text { New Zealand), CM(Canada, Mexico), } \\
\text { Central America, ASEAN, Middle East, } \\
\text { China, Russia, Iran, Rest of World(ROW) }\end{array}$} & Energy & $\begin{array}{l}\text { Coal, Oil, Gas, Petroleum, } \\
\text { Electricity }\end{array}$ \\
\hline & Non-Energy & $\begin{array}{l}\text { Agriculture Energy intensive } \\
\text { industries, Other industries, } \\
\text { services }\end{array}$ \\
\hline
\end{tabular}

Source: Authors' aggregation based on the scheme of the GTAP database.

Table 2 suggests major producers by each type of energy based on the GTAP-E DB v10. As the world's biggest energy supplier, the United States occupies more than $10 \%$ of the world's energy production in all types of energy, including coal, oil, gas, petroleum, electricity. The EU has conspicuous performance in producing electricity $(19.1 \%$ in the world) and coal (11.9\%) each. The Middle East has unparalleled competitiveness in producing oil (32.2\%) and gas (23.1\%), and Russia also has a substantial capacity in producing them. China is the world's biggest coal producer (37.9\%) and as well as the second-largest electricity producer next to the EU.

Table 2. Scale of output of energy in major countries (\%).

\begin{tabular}{cccccc}
\hline & Coal & Oil & Gas & Petroleum & Electricity \\
\hline USA & 12.7 & 11.9 & 15.8 & 17.1 & 14.9 \\
\hline EU & 4.9 & 4.4 & 9.7 & 16.7 & 19.1 \\
\hline ANZ & 11.9 & 0.6 & 2.6 & 0.9 & 1.6 \\
\hline ASEAN & 8.4 & 2.8 & 9.0 & 4.3 & 2.8 \\
\hline Middle East & 0.4 & 32.2 & 23.1 & 7.7 & 5.8 \\
\hline China & 38.2 & 5.0 & 1.0 & 15.9 & 17.0 \\
\hline Russia & 5.7 & 12.0 & 14.1 & 6.0 & 6.0 \\
\hline
\end{tabular}

Source: Authors' aggregation based on the GTAP-E database.

The GTAP-E DB organizes the transactions of each energy source between countries in multidimensional matrix forms. As its database is massive, major exporters and importers of oil are shown in Figure 4. 

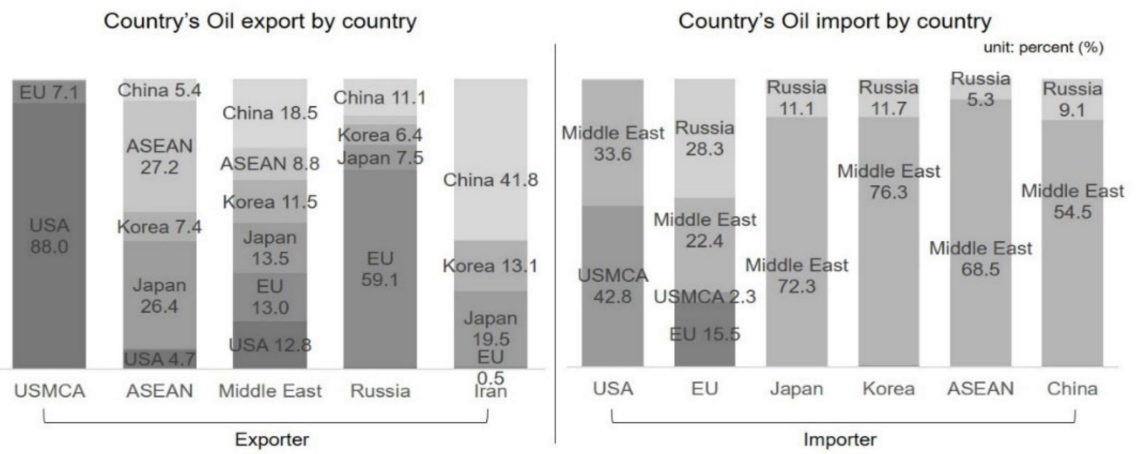

Figure 4. Country's Oil trade by country. Source: Author's calculation based on GTAP-E database.

\subsection{Simulation Scenarios}

The interrelationships between the various reverse-GVC factors make it difficult to estimate the effects of those factors. Decoupling between the United States and China is linked to protectionism, and COVID-19 has influenced both of them, which raises the possibility for reshoring and reverse-GVC.

To understand any linkages between the reverse-GVC factors, identifying the most important factor that causes reverse-GVC is necessary for the analysis. Covid-19 and the U.S. decoupling policy can be said the most significant factors causing the reverse-GVC phenomenon. Despite the efforts to form herd immunity through vaccination and prior infection, the effects of COVID-19 are likely to persist well into the future [6], and the Biden administration's decoupling policy may potentially further intensify these effects.

Existing studies on the effects of COVID-19 mostly estimated the economic crisis in 2020 and the subsequent policy measures followed by the pandemic. As aforementioned, the aftereffects of the pandemic are likely to prevail for a long period of time, which will further entrench protectionism. Moreover, reshoring and the reduction of GVC will further attenuate trade and economic activities. However, some studies, including McKinsey [45], forecast a 4-year delay until full recovery of worldwide GDP to the pre-COVID-19 level, assuming no other global risk.

As discussed previously, the U.S.-China hegemonic competition leads to decoupling which entails a huge shock of reverse-GVC, and the COVID-19 preventive measures and guidelines have further impacted the global economy and the energy market. The study scenarios categorize the countries participating in the U.S.-led decoupling into three groups: (i) active participants (Group 1; G1 hereafter) include Europe, Japan, Korea, Australia, New Zealand, Canada, and Mexico, (ii) passive participants (Group 2; G2) include Latin American and the Caribbean, the ASEAN, and the Middle East (except Iran), and lastly (iii) those who reluctantly participate (Group 3; G3) include all regions except China, Russia, and Iran (Table 3).

Table 3. Classification of participants in the U.S.-led decoupling from China.

\begin{tabular}{|c|c|c|c|}
\hline & $\begin{array}{c}\text { (i) Active } \\
\text { Participants (G1) }\end{array}$ & $\begin{array}{l}\text { (ii) Passive Participants } \\
\text { (G2) }\end{array}$ & $\begin{array}{l}\text { (iii) } \\
\text { Reluctant Participants (G3) }\end{array}$ \\
\hline Countries & $\begin{array}{c}\text { EU, Japan, Korea, } \\
\text { ANZ (Australia, } \\
\text { New Zealand), } \\
\text { CM(Canada, Mexico) }\end{array}$ & $\begin{array}{l}\text { Latin American and the } \\
\text { Caribbean, ASEAN, } \\
\text { Middle East (except Iran) }\end{array}$ & $\begin{array}{c}\text { The rest } \\
\text { (Except China, Russia, and } \\
\text { Iran) }\end{array}$ \\
\hline
\end{tabular}

Source: Authors' classification based on the US' strategy.

Next, we set up scenarios of the level of strength in the U.S.-led decoupling policies and the preventive measures against COVID-19. Based on our assumption that COVID-19 and decoupling policies are persistent as protectionist measures, the WTO is irrelevant. Measures related to public health are at each country's own discretion according to Article 21 of GATT; thus it is difficult to review treaty violations. Quantifying the currently 
placed measures by each country in the customs clearance processes as ad valorem tariffs is a very challenging task that is ignored herein and recommended as a separate research topic. Thus, this paper applies several scenarios to estimate the effects of the reverse GVC factors on the global economy.

First, scenarios of the levels of the United States' measures for decoupling are set up to estimate the ripple effect. Apart from the export control measures that directly exclude businesses such as Huawei from GVC by indicating them on an entity list for national security reasons, imposing tariffs based on Section 301 of the Trade Act of 1974 and Section 232 of the Trade Expansion Act of 1962 are critical tools for the U.S.-China decoupling. As seen in the U.S.-China meeting in Alaska in March, 2021, the Biden administration has no intention in terminating the $7.5 \sim 25 \%$ of tariffs imposed by the Trump administration on the $\$ 370$ trillion worth of the Chinese goods, despite industrial sectors request to reconsider. According to the U.S. Chamber of Commerce [53], in the worse scenario, the United States can impose $25 \%$ tariffs on all the imports from China and impose comparable measures on those countries that do not participating in its plan of decoupling. This study also adopts such measures as decoupling in general, but sets up several other scenarios with partial modifications, as presented at Table 4.

Table 4. Scenarios on decoupling and the effects of COVID-19.

\begin{tabular}{|c|c|c|c|c|c|}
\hline & \multicolumn{4}{|c|}{ China Decoupling (tms) } & \multirow[b]{2}{*}{$\begin{array}{l}\text { COVID-19 } \\
\text { (ams) }\end{array}$} \\
\hline & USA & $\begin{array}{c}\text { Active } \\
\text { Participants (G1) }\end{array}$ & $\begin{array}{c}\text { Passive } \\
\text { Participants (G2) }\end{array}$ & $\begin{array}{c}\text { Reluctant } \\
\text { Participants (G3) }\end{array}$ & \\
\hline S1 & $+10 \%$ & $+10 \%$ & $+5 \%$ & $+3 \%$ & \multirow{4}{*}{$-10 \%$} \\
\hline S2 & $+15 \%$ & $+15 \%$ & $+10 \%$ & $+5 \%$ & \\
\hline S3 & $+25 \%$ & $+20 \%$ & $+15 \%$ & $+10 \%$ & \\
\hline S4 & $+30 \%$ & $+25 \%$ & $+20 \%$ & $+15 \%$ & \\
\hline
\end{tabular}

The scenarios are broadly classified into those for decoupling and the effects of COVID-19, and Scenario 1, which has relatively weaker strength in sanctions against China, is the China decoupling strategy. This assumes that the United States will increase tariffs (GTAP variable tms in Table 4 ) on Chinese imports by $10 \%$, on imports of G1 by $10 \%$, G2 by $5 \%$, and G3 by $3 \%$. Scenario 2 is the most plausible one and has tariff charges that are $2 \sim 5 \%$ higher than those in Scenario 1. Scenario 4 has a high level of decoupling measures (intense reverse-GVC), and has higher tariff barriers on the Chinese imports by $12 \sim 20 \%$ compared to Scenario 1, ultimately experiencing a drastic reduction in GVCs with China.

For the reverse-GVC effects of COVID-19, it is assumed that countries will increase non-tariff barriers as protectionist measures. As empirically estimating the custom duties of non-tariff barriers is a large-scale research project that can be a separate research topic itself, this study creates scenarios on the COVID-19 preventive measures in order to focus mostly on decoupling from China and the potential extension of COVID-19. The reverse-GVC effects due to COVID-19 are assumed to decrease the efficiency of global logistics (variable ams) by $10 \%$, which increases global trade costs.

\section{Simulation Results and Interpretation}

\subsection{The Effects on GDP by Scenarios}

All reverse-GVC scenarios entail a loss for every country (Table 5). This has already been pointed out in many previous studies, including Bonadio et al. [7] and more. These losses expand as decoupling intensifies. The United States is expected to suffer the smallest percentage GDP loss, unlike previous studies, such as Hanson [51]. And in absolute GDP, the United States' loss will be the largest, followed in order by the EU and China. ASEAN (GDP loss of more than $6 \%$ in all scenarios), South Korea, then the EU will suffer the greatest reduction in percentage GDP. 
Table 5. The reverse-GVC effects on GDP by scenarios.

\begin{tabular}{|c|c|c|c|c|c|c|c|c|c|}
\hline & & \multicolumn{2}{|c|}{ Scenario 1} & \multicolumn{2}{|c|}{ Scenario 2} & \multicolumn{2}{|c|}{ Scenario 3} & \multicolumn{2}{|c|}{ Scenario 4} \\
\hline & & $\%$ & \$, billion & $\%$ & \$, billion & $\%$ & \$, billion & $\%$ & $\$$, billion \\
\hline \multicolumn{2}{|c|}{ USA } & -1.64 & -285 & -1.62 & -281 & -1.74 & -301 & -1.76 & -305 \\
\hline \multirow{5}{*}{ G1 } & EU & -4.97 & -976 & -4.96 & -982 & -4.97 & -980 & -4.97 & -983 \\
\hline & Japan & -2.68 & -121 & -2.71 & -123 & -2.74 & -124 & -2.68 & -126 \\
\hline & Korea & -5.69 & -79 & -5.73 & -80 & -5.82 & -81 & -5.69 & -82 \\
\hline & ANZ & -2.33 & -38 & -2.35 & -39 & -2.38 & -39 & -2.33 & -39 \\
\hline & $\mathrm{CM}$ & -3.97 & -120 & -3.95 & -122 & -3.98 & -122 & -3.97 & -123 \\
\hline \multirow{3}{*}{ G2 } & $\mathrm{CA}$ & -5.47 & -12 & -5.44 & -12 & -5.48 & -12 & -5.47 & -12 \\
\hline & ASEAN & -6.17 & -154 & -6.18 & -156 & -6.24 & -156 & -6.17 & -158 \\
\hline & ME & -3.85 & -146 & -3.85 & -147 & -3.87 & -147 & -3.85 & -148 \\
\hline G3 & ROW & -2.91 & -321 & -2.89 & -320 & -2.9 & -318 & -2.91 & -320 \\
\hline \multirow{3}{*}{ Other } & China & -3.35 & -331 & -3.65 & -347 & -3.84 & -377 & -3.35 & -398 \\
\hline & Russia & -3.12 & -64 & -3.06 & -63 & -3.02 & -62 & -3.12 & -61 \\
\hline & Iran & -2.45 & -11 & -2.19 & -10 & -1.99 & -9 & -2.45 & -8 \\
\hline
\end{tabular}

Source: Authors' calculation.

\subsection{The Reverse-GVC Effects}

We next examine the level of reverse-GVC in terms of the changes in the GVC indices under each scenario by using the GTAP-VA model. The GVC index has been adopted by many international organizations, such as the UNCTAD [78] and OECD [79], according to the following method of calculation:

\section{GVA Participation Index $=($ FVA + DVX $) /$ Gross Exports}

Here, the FVA, which is foreign VA used for the total exports, and the DVX, which is the domestic VA, are added together, then divided by the gross exports, yielding the GVC index [78]. This study calculates the effects on GVC based on the scenarios for decoupling through the changes in the GVC indices compared to the GVC index of the baseline (Table 6).

The increased trade costs due to the global decoupling policy and COVID-19 reduce the GVC indices by $0.53 \sim 1.32 \%$. The ASEAN will experience the largest reduction in the GVC indices from $0.20 \sim 1.15 \%$, followed by Korea $(-0.26 \sim-0.78 \%)$, Japan $(-0.34 \sim-0.64 \%)$, China $(-0.05 \sim-0.18 \%)$ and other Asian countries that have displayed a large reduction in their GVC indices. Yet, the GVC index of China, which is the subject of US tariffs, was lower than that of Korea or Japan, and it does not seem to be significantly larger than the global GVC reduction.

Some countries are expected to experience an increase in the GVC participation rate even under the decoupling and the pandemic: Russia (2.05 2.14\%), CM (0.77 1.02\%), and the United States $(0.48 \sim 0.58 \%)$. It is interpreted as Russia and China strengthen the GVCs with the reverse GVC factors, and CM countries substitute original GVCs with China by integrating the GVCs within the North American region. 
Table 6. GVC indices and rate of change. (unit: \%, \%p).

\begin{tabular}{|c|c|c|c|c|c|c|c|c|c|c|}
\hline & & \multirow{2}{*}{$\begin{array}{l}\text { Baseline } \\
\text { (A) }\end{array}$} & \multicolumn{2}{|c|}{ Scenario1 } & \multicolumn{2}{|c|}{ Scenario2 } & \multicolumn{2}{|c|}{ Scenario3 } & \multicolumn{2}{|c|}{ Scenario4 } \\
\hline & & & B & A-B & C & A-C & D & A-D & $E$ & A-E \\
\hline \multicolumn{2}{|c|}{ USA } & 43.0 & 43.5 & 0.52 & 43.6 & 0.58 & 43.5 & 0.48 & 43.5 & 0.49 \\
\hline \multirow{5}{*}{ G1 } & EU & 16.8 & 16.8 & 0.00 & 16.6 & -0.20 & 16.5 & -0.27 & 16.4 & -0.37 \\
\hline & Japan & 52.6 & 52.3 & -0.34 & 52.2 & -0.46 & 52.1 & -0.55 & 52.0 & -0.64 \\
\hline & Korea & 59.8 & 59.6 & -0.26 & 59.4 & -0.42 & 59.2 & -0.64 & 59.0 & -0.78 \\
\hline & ANZ & 41.4 & 41.5 & 0.16 & 41.5 & 0.09 & 41.4 & 0.02 & 41.3 & -0.03 \\
\hline & $\mathrm{MC}$ & 46.9 & 47.2 & 0.28 & 47.0 & 0.09 & 47.2 & 0.31 & 47.2 & 0.26 \\
\hline \multirow{3}{*}{ G2 } & CA & 37.3 & 38.4 & 1.02 & 38.1 & 0.77 & 38.3 & 0.97 & 38.2 & 0.91 \\
\hline & ASEAN & 42.4 & 42.2 & -0.20 & 41.7 & -0.71 & 41.5 & -0.88 & 41.2 & -1.15 \\
\hline & $\mathrm{CM}$ & 26.1 & 27.0 & 0.88 & 27.0 & 0.85 & 27.0 & 0.87 & 27.0 & 0.89 \\
\hline G3 & ROW & 34.5 & 34.9 & 0.44 & 34.9 & 0.40 & 34.7 & 0.23 & 34.5 & 0.01 \\
\hline \multirow{3}{*}{ Other } & China & 56.2 & 56.1 & -0.05 & 56.1 & -0.04 & 56.0 & -0.15 & 56.0 & -0.18 \\
\hline & Russia & 39.3 & 41.4 & 2.05 & 41.4 & 2.07 & 41.4 & 2.10 & 41.4 & 2.14 \\
\hline & Iran & 27.4 & 28.3 & 0.86 & 28.2 & 0.84 & 28.2 & 0.77 & 28.2 & 0.77 \\
\hline \multicolumn{2}{|c|}{ Total } & 33.8 & 33.3 & -0.53 & 33.0 & -0.79 & 32.7 & -1.08 & 32.5 & -1.32 \\
\hline
\end{tabular}

Notes: The rate of change means the relative rate of change compared to the baseline. Source: Authors' calculation.

\subsection{The Effects on the Global Energy Market}

The effects of COVID-19 and decoupling on energy usage will differ substantially among the countries (Table 7). Firstly, followed by decoupling, the United States will not experience significant impacts on its usage of energy, including oil and petroleum, whereas China certainly will. China's usage of oil is expected to decreased by $7.6 \%$ at minimum and $13.2 \%$ at maximum, and its usage of gas and petroleum will also be reduced by $10.5 \%$ at minimum and $13.0 \%$ at maximum. Similarly, for Korea, coal will be reduced by $7.4 \%$ at maximum, oil by $10.6 \%$ at maximum, gas by $9.8 \%$ at maximum, and petroleum by $9.0 \%$ at maximum. Korea is one of the countries with the most intimate GVC ties with China; thus, such significant impact caused by COVID-19 and decoupling is inevitable.

Table 7. Analysis results of change in energy usage due to reverse-GVC by countries. (unit: \%).

\begin{tabular}{|c|c|c|c|c|c|}
\hline & & Coal & Oil & Gas & Petroleum \\
\hline \multicolumn{2}{|r|}{ USA } & $(0.1,0.2)$ & $(-5.1,-5.2)$ & $(-0.2,-0.2)$ & $(-4.5,-4.0)$ \\
\hline \multirow{5}{*}{ G1 } & EU & $(-4.2,-4.3)$ & $(-10.0,-10.5)$ & $(-6.8,-6.9)$ & $(-11.2,-10.8)$ \\
\hline & Japan & $(-5.0,-5.2)$ & $(-6.1,-6.4)$ & $(-6.0,-6.2)$ & $(-7.0,-6.9)$ \\
\hline & Korea & $(-7.1,-7.4)$ & $(-10.6,-10.6)$ & $(-9.2,-9.8)$ & $(-8.8,-9.0)$ \\
\hline & ANZ & $(0.6,0.1)$ & $(-3.1,-3.2)$ & $(0.2,0.8)$ & $(-8.6,-9.0)$ \\
\hline & $\mathrm{MC}$ & $(0.5,0.7)$ & $(3.2,3.3)$ & $(1.0,1.6)$ & $(-4,-3.6)$ \\
\hline \multirow{3}{*}{ G2 } & CA & $(-5.3,-5.8)$ & $(7.3,8.6)$ & $(-0.5,0.4)$ & $(-12.9,-12.6)$ \\
\hline & ASEAN & $(0.0,0.2)$ & $(-4.6,-5.5)$ & $(2.5,2.6)$ & $(-9.6,-9.3)$ \\
\hline & $\mathrm{CM}$ & $(-3.4,-3.1)$ & $(5.0,5.6)$ & $(1.0,1.3)$ & $(-3.3,-2.8)$ \\
\hline G3 & ROW & $(-1.0,-1.0)$ & $(-1.8,-1.1)$ & $(-0.6,-0.8)$ & $(-5,-4.7)$ \\
\hline \multirow{3}{*}{ Other } & China & $(-1.5,-2.5)$ & $(-7.6,-13.2)$ & $(-6.2,-10.5)$ & $(-7.8,-13.0)$ \\
\hline & Russia & $(1.4,1.7)$ & $(4,4.5)$ & $(0.9,0.8)$ & $(0.6,0.9)$ \\
\hline & Iran & $(2.5,2.3)$ & $(2.8,2.7)$ & $(0.7,-0.6)$ & $(-0.2,-0.1)$ \\
\hline
\end{tabular}

Notes: (min, max) mean minimum and maximum values by scenarios. Source: Authors' calculation. 
Although Table 5 showed that the ASEAN's GDP will be largely reduced, Table 8 suggests that the energy consumption of the ASEAN states will be less weakened and even increase by energy source because they can take advantage when China is excluded from the GVCs. Table 8 shows that all countries/regions reduce imports of energy intensive products from China, and ultimately increase their trade with the ASEAN as a substitute.

Table 8. The effects on imports of Chinese Energy Intensive products. (unit: \%).

\begin{tabular}{|c|c|c|c|}
\hline & & from China & from ASEAN \\
\hline \multicolumn{2}{|c|}{ USA } & $(-30.7,-51.8)$ & $(0.1,4.6)$ \\
\hline \multirow{5}{*}{ G1 } & EU & $(-26.7,-36.4)$ & $(5.6,6.9)$ \\
\hline & Japan & $(-33.4,-43.1)$ & $(-3.8,-3.6)$ \\
\hline & Korea & $(-29.8,-40.1)$ & $(-1.5,1.5)$ \\
\hline & ANZ & $(-32.3,-42.5)$ & $(-2.2,-2.4)$ \\
\hline & $\mathrm{MC}$ & $(-23.7,-32.5)$ & $(10.1,14.3)$ \\
\hline \multirow{3}{*}{ G2 } & CA & $(-3.8,-13.1)$ & $(7.6,12.8)$ \\
\hline & ASEAN & $(-8.8,-23.0)$ & $(-2.2,0.4)$ \\
\hline & $\mathrm{CM}$ & $(-3.7,-19.7)$ & $(3.2,5.3)$ \\
\hline G3 & ROW & $(2.9,-0.9)$ & $(-2.4,-1.7)$ \\
\hline
\end{tabular}

Notes: (min, max) mean minimum and maximum values by scenarios. Source: Authors' calculation.

It is expected that COVID-19 and decoupling will combine to reduce the global GDP and weaken the GVCs. Due to the decrease in energy demand, the energy exports of major energy suppliers will be largely weakened as seen Table 9. All values presented here are those under the newly formed equilibrium after the reverse-GVC shock has been applied, and the effects on the final volume in energy exports are presented in the table. The United States may experience a reduction in oil and gas exports by more than $50 \%$, and China a reduction in its coal and petroleum exports by up to $29.3 \%$ and $44.0 \%$, respectively. Also, the gas exports of the Middle East and Russia will be greatly decreased.

Table 9. Impacts on volume of exports of major countries by sources of energy. (unit: \%).

\begin{tabular}{ccccc}
\hline & Coal & Oil & Gas & Petroleum \\
\hline USA & $(-19.4,-23.0)$ & $(-52.8,-54.0)$ & $(-59.6,-61.7)$ & $(-16.4,-16.2)$ \\
\hline China & $(-21.6,-29.3)$ & - & - & $(-24.6,-44.0)$ \\
\hline Middle East & - & $(-4.1,-5.3)$ & $(-26.7,-28.2)$ & - \\
\hline Russia & - & $(-7.0,-8.2)$ & $(-25.8,-22.5)$ & - \\
\hline
\end{tabular}

Source: Authors' calculation.

As the major countries' exports decrease, the global energy trade will also be reduced. The estimation results presented in Table 10 suggest that the reverse-GVC factors, such as COVID-19 and the China decoupling policies, will significantly affect the global energy market. The international gas trade volume will be reduced by $27.3 \%$ at minimum and by $38.6 \%$ at maximum; thus the impact of the reverse-GVC factors is expected to be even more severe. On the other hand, the effects on other energy sources will be relatively small. The international coal, oil and petroleum trades will be reduced by up to $8.9 \%, 6 \%$ and $3.3 \%$, respectively. 
Table 10. Impacts of reverse-GVC factors on global energy market. (unit: \%).

\begin{tabular}{ccccc}
\hline & \multicolumn{4}{c}{ Energy } \\
\cline { 2 - 5 } & Coal & Oil & Gas & Petroleum \\
\hline Global trade value & $(-6.5,-8.9)$ & $(-6.0,-6.0)$ & $(-27.3,-38.6)$ & $(-2.6,-3.3)$ \\
\hline Notes: (min, max) mean minimum and maximum values by scenarios. Source: Authors' calculation.
\end{tabular}

\subsection{Discussion on Reverse GVC and the Future Energy Market}

As Nature [6] points out, it is difficult to view the global economy optimistically even with the possibility of forming a collective immunity by vaccinating COVID-19. The global economy and international trade order have changed significantly due to several adverse GVC factors. The fact that GVC has been under adjustment pressure in the last 2-3 years also darkens the outlook for international trade and global energy markets. The COVID-19 pandemic is further heightening the U.S.-China conflict and applying pressure to adjust the GVC. The current President Biden is pursuing a stronger policy toward China than former President Trump, increasing the pressure for the GVC adjustment.

As GVC is adjusted, the global energy market is expected to contract. The impact on energy usage varies by country, but it is expected to have a large impact on the US and China. US oil and gas exports will decline. The exports of the major energy suppliers will be reduced by up to $50 \%$, and the global energy market will also shrink by $30 \sim 40 \%$, depending on the scenario. Moreover, as the Biden administration pushes for carbon emissions reductions on climate change, the demand for fossil energy could be further reduced. This will darken the outlook for a resource-dependent economy, and will act as the cause of the global energy market stagnation. Considering the current Biden administration's "by American" policy and global environmental policy, the actual impact could be greater than the estimates in this study.

Although not analyzed in this paper, COVID-19 acts as a logic to strengthen the international community's cooperation to cope with climate change, and as a result, the global energy market may undergo structural changes. This point has been pointed out in a number of studies. Fuentes, et al. [80] found that the COVID-19 pandemic and climate change share "the same microeconomic foundations involving an overprovision of a global public bad". Antonio and Garcia [81] wrote that "COVID-19 has had a mainly negative effect on the energy transition", and Nyga-Łukaszewska and Aruga [82] assessed the pandemic and its continuing threat to have changed human behavioral patterns saving energy.

In this paper, we suggested that COVID-19 and decoupling could lead to losses in the global economy. In particular, it is expected that the GVC damage in East Asian countries, including Korea and ASEAN countries, is greater than in other regions. This is the opposite analysis result from the study in Gentile et al. [83]. They predicted that several East Asian countries could expect the benefits of a trade diversion as the U.S. cuts trade with China due to the bilateral trade war. This result can be achieved by reflecting only the US' tariff imposition on China as a shock using a typical CGE model. This is too naïve approach, ignoring the effects of adverse factors. Concerned about this, our study was able to derive more realistic estimation results than previous studies by using the modules of GTAP-E and GTAP-VA that can estimate the adverse GVC effects.

When the global economy deteriorated, there were many independent measures such as strengthening trade protection rather than international cooperation as discussed by Miroudot \& Nordström [8]. Rather than targeting a niche market caused by changes in trade order, each country should prioritize efforts to minimize the damage to global economy. In particular, the global energy market is under the direct and indirect influence of the COVID-19 pandemic, and as Nyga-Łukaszewska and Aruga [83] pointed out, large companies can survive because of 'too big to fail', but small energy companies may face management difficulties. US' return to the Paris Climate Change Agreement meant restoring the international cooperation system, but the Biden Administration is pushing the 
decoupling policy toward China. In addition, they are all-in on establishing GVC within the US under the "Buy American" initiative. In this situation, if the climate change issue is used as a means of strengthening US hegemony, the global energy market will be impacted more rapidly.

\section{Conclusions}

Globalization has been expanding international trade and GVC until recently. Accordingly, the global energy market experienced a boom, while GVCs were deepened and expanded, accompanied by increased technology transfer, investment and labor movement, and job creation. As awareness of the importance of GVC resilience spreads, GVC has tended to shrink. On top of this, the intensification of the U.S.-China conflict and COVID-19 have undoubtedly induced reverse-GVC. Technology transfer, investment, and labor movement, which had previously facilitated GVC expansion, are now facing global constraints. Moreover, the rapid transition to a digital economy, which has been further accelerated by COVID-19, will structurally alter production systems and eventually weaken the GVC, as UNCTAD [23] and UNIDO [1] predict.

This paper applied the modules of the GTAP-E and the GTAP-VA to the GTAP CGE model in order to analyze the impacts of the reverse-GVC factors. Simulation results suggest that the reverse-GVC factors will substantially affect the global economy and energy market. Although other studies have claimed that the reverse-GVC factors will weaken international trade, the present study is the first to empirically estimate the effects on the global energy market using the CGE model. This paper is significant as it is the first to empirically estimate such ripple effects, and it also provides important policy suggestions to industries and policymakers in each country. The recession in the global energy market weakens investments in relevant industries and therefore damages the global energy supply infrastructures in the long-term.

Nevertheless, the following research avenues are left for future study. First, to estimate the COVID-19 effects more accurately, non-tariff barriers must be calculated. Second, the GTAP-E module and the VA module should be merged in order to assess the impact of GVC changes on the global energy market. Future research will overcome these limitations by considering the importance of these issues.

Author Contributions: Conceptualization, B.L. and I.C.; methodology, J.Y. and I.C.; formal analysis, B.L. and K.H.; investigation, K.H. and I.C.; data curation, J.Y. and I.C.; writing-original draft preparation, K.H. and I.C.; writing-review and editing, K.H.; visualization, J.Y. and I.C.; project administration, I.C. and B.L. All authors have read and agreed to the published version of the manuscript.

Funding: This research received no external fundings.

Institutional Review Board Statement: Not applicable.

Informed Consent Statement: Not applicable.

Data Availability Statement: Not applicable.

Conflicts of Interest: The authors declare no conflict of interest.

\section{References}

1. UNIDO. Could the Coronavirus Spur Automation and Reverse Globalization? 2020. Available online: https:/ /iap.unido.org/ articles/could-coronavirus-spur-automation-and-reverse-globalization (accessed on 3 April 2021).

2. Blanchard, E. Trade Wars in The Global Value Chain Era. VoxEU.org. 2019. Available online: https://voxeu.org/article/tradewars-global-value-chain-era (accessed on 3 March 2021).

3. Bolwijn, R.; Casella, B.; Zhan, J. International production and the digital economy. In International Business in the Information and Digital Age (Progress in International Business Research); Tulder, R., Verbeke, A., Piscitello, L., Eds.; Emerald Publishing: Bingley, UK, 2019; Volume 13, pp. 39-64, ISBN 978-1-78756-325-4.

4. Uetz, A.M.; Miller, V.L.; Kalyvas, J.R.; Wergzyn, K.E. Accelerating Trends: Assessing the Supply Chain in a Post-Pandemic World. 2020. Available online: https://www.foley.com/en/insights/publications/2020/09/accelerating-trends-supply-chain-postpandemic (accessed on 3 April 2021). 
5. Emont, J. The Robots are Coming for Garment Workers. That's Good for the U.S., Bad for Poor Countries. 2020. Available online: https:/ / www.wsj.com/articles/the-robots-are-coming-for-garment-workers-thats-good-for-the-u-s-bad-for-poorcountries-1518797631 (accessed on 3 April 2021).

6. Nature. Five Reasons Why COVID Herd Immunity Is Probably Impossible. 2021. Available online: https:/ /www.nature.com/ articles/d41586-021-00728-2 (accessed on 5 April 2021).

7. Bonadio, B.; Huo, Z.; Levchenko, A.; Pandalai-Nayar, N. Global Supply Chains in the Pandemic. National Bureau of Economic Research. Working Paper 27224. 2020. Available online: https:/ / www.nber.org/papers/w27224 (accessed on 4 April 2021).

8. Miroudot, S.; Nordström, H. Made in the world? Global value chains in the midst of rising protectionism. Rev. Ind. Organ. 2020, 57, 1-28. [CrossRef]

9. Organisation for Economic Co-operation and Development. Shocks, Risks and Global Value Chains: Insights from the OECD METRO Model; OECD Publishing: Paris, France, 2020.

10. Javorcik, B. Global supply chains will not be the same in the post-COVID-19 world. In COVID-19 and Trade Policy: Why Turning Inward Won't Work; Baldwin, R., Evenett, S.J., Eds.; CEPR Press: London, UK, 2020; pp. 111-116.

11. Miroudot, S. Reshaping the policy debate on the implications of COVID-19 for global supply chains. J. Int. Bus. Policy 2020, 3 , 430-442. [CrossRef]

12. Gibbon, P.; Ponte, S. Global value chains: From governance to governmentality? Econ. Soc. 2008, 37, 365-392. [CrossRef]

13. Henderson, J.; Dicken, P.; Hess, M.; Coe, N.; Yeung, H. Global production networks and the analysis of economic development. Rev. Int. Polit. Econ. 2002, 9, 436-464. [CrossRef]

14. Haakonsson, S.J. Learning by importing in global value chains: Upgrading and South-South strategies in the Ugandan pharmaceutical industry. Dev. South. Afr. 2009, 26, 499-516. [CrossRef]

15. Rabellotti, R. Upgrading in Global Value Chains: The Role of Knowledge and Technological Capabilities. Presentation Prepared for UNCTAD. 2014. Available online: https:/ / unctad.org/system/files/non-official-document/MYEM2_2014_Roberta_Rabellotti. pdf (accessed on 16 March 2021).

16. Raei, F.; Anna, I.; Borislava, M. Global Value Chains: What Are the Benefits and Why Do Countries Participate? IMF Working Papers 2019/018, International Monetary Fund. 2019. Available online: https://www.imf.org/en/Publications/WP/Issues/2019/0 1/18/Global-Value-Chains-What-are-the-Benefits-and-Why-Do-Countries-Participate-46505 (accessed on 3 April 2021).

17. Vidrova, Z. Supply chain management in the aspect of globalization. SHS Web Conf. 2020, 74, 04031. [CrossRef]

18. Ossa, R. Why trade matters after all. J. Int. Econ. 2015, 97, 266-277. [CrossRef]

19. Li, B.; Liu., Y. Moving Up the Value Chain; Boston University: Boston, MA, USA, Unpublished work.

20. Halpern, L.; Koren, M.; Szeidl, A. Imported inputs and productivity. Am. Econ. Rev. 2015, 105, 3660-3703. [CrossRef]

21. Barrientos, S.; Gereffi, G.; Rossi, A. Economic and social upgrading in global production networks: A new paradigm for a changing world. Int. Labour. Rev. 2011, 150, 319-340. [CrossRef]

22. Cattaneo, O.; Gereffi, G.; Staritz, C. Global Value Chains in a Postcrisis World: A Development Perspective; World Bank: Washington, DC, USA, 2010; ISBN 978-0-8213-8499-2.

23. UNCTAD. World Investment Report 2020: International Production Beyond the Pandemic; United Nations: New York, NY, USA, 2020; ISBN 978-92-1-112985-4.

24. McKinsey Global Institute. Resource Revolution: Tracking Global Commodity Markets, Trends Survey. 2013. Available online: https:/ / www.mckinsey.com/ \{\}/media/McKinsey/Not\%20Mapped/TEST\%20Copy\%20of\%20Resource\%20revolution\%20 Tracking\%20global\%20commodity\%20markets/MGI_Resources_survey_Full_report_Sep2013.pdf (accessed on 12 December 2020).

25. Goldman Sachs. Commodities Outlook: REVing Up a Structural Bull Market. 2020. Available online: https://www.goldmansachs. com/insights/podcasts/episodes/12-15-2020-jeff-currie.html (accessed on 3 April 2021).

26. McKinsey. Global Oil Outlook to 2040, Energy Insights. 2021. Available online: https://www.mckinsey.com/ \{\}/media/ McKinsey/Industries/Oil\%20and\%20Gas/Our\%20Insights/Global\%20oil\%20supply\%20and\%20demand\%20outlook\%20to\% 202040/Global-oil-supply-and-demand-outlook-to-2040-Online-Summary.pdf (accessed on 12 March 2021).

27. Christopher, M.; Peck, H. Building the resilient supply chain. Int. J. Logist. Manag. 2004, 15, 1-13. [CrossRef]

28. Christopher, M.; Holweg, M. "Supply chain 2.0": Managing supply chains in the era of turbulence. Int. J. Phys. Distrib. Logist. Manag. 2011, 41, 63-82. [CrossRef]

29. Zhan, J. G20 Guiding Principles for Global Investment Policymaking: A Facilitator's Perspective; International Centre for Trade and Sustainable Development: Geneva, Switzerland, 2016.

30. De Backer, K.; Dorothee, F. The Future of Global Value Chains, Business as Usual or a New Normal? 2017. Available online: https:/ / www.oecd-ilibrary.org/science-and-technology/the-future-of-global-value-chains_d8da8760-en (accessed on 5 April 2021).

31. Gereffi, G. Global value chains in a post-Washington consensus world. Rev. Int. Polit. Econ. 2014, 21, 9-37. [CrossRef]

32. Meltzer, J.P. The internet, cross-border data flows and international trade. Asia Pac. Policy Stud. 2014, 2, 90-102. [CrossRef]

33. Azmeh, S.; Christopher, F.; Jaime, E. The international trade regime and the quest for free digital trade. Int. Stud. Rev. 2020, 22, 671-692. [CrossRef]

34. Timbie, J. National Security Supply Chain Resilience. 2021. Available online: https://www.hoover.org/research/nationalsecurity-supply-chain-resilience (accessed on 3 April 2021).

35. US Department of State. Military-Civil Fusion and the People's Republic of China. US DOS Fact Sheet. 2020. Available online: https:/ / www.state.gov/wp-content/uploads/2020/05/What-is-MCF-One-Pager.pdf (accessed on 5 April 2021). 
36. Kearney, A.T. Trade War Spurs Sharp Reversal in 2019 Reshoring Index, Foreshadowing COVID-19 Test of Supply Chain Resilience. 2020. Available online: https:/ /www.wita.org/atp-research/trade-war-spurs-sharp-reversal-in-2019/ (accessed on 1 April 2021).

37. Brian, G.A. Heightened Focus on Reshoring. 2020. Available online: https://www.areadevelopment.com/BusinessGlobalization/ Q3-2020/a-heightened-focus-on-reshoring.shtml (accessed on 1 January 2021).

38. Financial Times. Covid-19: How Close is the Light at the End of the Tunnel? 2021. Available online: https://www.ft.com/ content/42a98c9e-fa47-4792-8beb-4504503c7910 (accessed on 3 April 2021).

39. Coates, R. Challenges of Moving Manufacturing Out of China. 2021. Available online: https://www.areadevelopment.com/ BusinessGlobalization/Q1-2021/challenges-of-moving-manufacturing-out-of-china.shtml (accessed on 1 April 2021).

40. Reshoring Initiative. Despite COVID, Reshoring is Up in 2020. Job Announcements for 2020 are Projected to Reach 110,000, Which Will Bring the Total Since 2010 to Over 1 Million By Year's End. 2020. Available online: https:/ / reshorenow.org/November-17-2 020/ (accessed on 3 April 2021).

41. Manufacturing Net. The Impact of Biden's Plan on Reshoring Trends “Buy American" Will Borrow Some Strategies from the Trump Administration in Targeting China and Fueling Growth at Home. 2021. Available online: https://www.manufacturing. net/trade/article/21295318/bidens-plan-could-fuel-reshoring (accessed on 3 April 2021).

42. IMF. World Economic Outlook. The Great Lockdown. 2020. Available online: https://www.imf.org/en/Publications/WEO/ Issues/2020/04/14/weo-april-2020 (accessed on 3 April 2021).

43. WTO. Trade Falls Steeply in First Half of 2020. 2020. Available online: https://www.wto.org/english/news_e/pres20_e/pr858 _e.htm (accessed on 3 April 2021).

44. European Commission. The Impact of the Covid-19 Pandemic on Global and EU Trade. Chief Economist Team, DG Trade. 2020. Available online: https:/ /trade.ec.europa.eu/doclib/docs/2020/may/tradoc_158764.pdf (accessed on 11 September 2020).

45. McKinsey. Global Freight Flows after COVID-19: What's Next? 2020. Available online: https://www.mckinsey.com/industries/ travel-logistics-and-infrastructure/our-insights/global-freight-flows-after-covid-19-whats-next (accessed on 3 April 2021).

46. Steinbock, D. U.S.-China trade war and its global impacts. China Q. Int. Strateg. Stud. 2018, 4, 515-542. [CrossRef]

47. Goulard, S. The impact of the US-China trade war on the European Union. Glob. J. Emerg. Mark. Econ. 2020, 12, 56-68. [CrossRef]

48. UNCTAD. Trade War Leaves Both US and China Worse Off. 2019. Available online: https://unctad.org/news/trade-war-leavesboth-us-and-china-worse (accessed on 5 April 2021).

49. Mao, H.; Görg, H. Friends like this: The impact of the US-China trade war on global value chains. World Econ. 2020, 43, 1776-1791. [CrossRef]

50. Itakura, K. Evaluating the impact of the US-China trade war. Asian Econ. Policy Rev. 2020, 15, 77-93. [CrossRef]

51. Hanson, G.H. The impacts of the U.S.-China trade war. Bus. Econ. 2020, 55, 69-72. [CrossRef]

52. Hass, R.; Denmark, A. More Pain Than Gain: How the US-China Trade War Hurt America. 2020. Available online: https://www. brookings.edu/blog/order-from-chaos/2020/08/07/more-pain-than-gain-how-the-us-china-trade-war-hurt-america/ (accessed on 5 April 2021).

53. U.S. Chamber of Commerce. Understanding U.S.-China Decoupling: Macro Trends and Industry Impacts. 2021. Available online: https:/ / www.uschamber.com/sites/default/files/024001_us_china_decoupling_report_fin.pdf (accessed on 3 April 2021).

54. Cole, M.A. Does trade liberalization increase national energy use? Econ. Lett. 2006, 92, 108-112. [CrossRef]

55. Narayan, P.K.; Smyth, R. Multivariate granger causality between electricity consumption, exports and GDP: Evidence from a panel of Middle Eastern countries. Energy Policy 2009, 37, 229-236. [CrossRef]

56. Lean, H.H.; Smyth, R. Multivariate Granger causality between electricity generation, exports, prices and GDP in Malaysia. Energy 2010, 35, 3640-3648. [CrossRef]

57. Shahbaz, M.; Nasreen, S.; Ling, C.H.; Sbia, R. Causality between trade openness and energy consumption: What causes what in high, middle and low income countries. Energy Policy 2014, 70, 126-143. [CrossRef]

58. Palamalai, S.; Ravindra, I.S.; Prakasam, K. Relationship between energy consumption, $\mathrm{CO}_{2}$ emissions, economic growth and trade in India. J. Econ. Financ. Stud. 2014, 3, 1. [CrossRef]

59. Shahzad, S.J.H.; Kumar, R.R.; Zakaria, M.; Hurr, M. Carbon emission, energy consumption, trade openness and financial development in Pakistan: A revisit. Renew. Sustain. Energy Rev. 2017, 70, 185-192. [CrossRef]

60. Arif, I.; Kazmi, S.W.; Khan, L. Relationship between trade openness and energy consumption in oil importing Asian countries. J. Financ. Econ. Res. 2017, 2, 33-42. [CrossRef]

61. Chaudhry, I.; Safdar, N.; Farooq, F. Energy consumption and economic growth: Empirical evidence from Pakistan. Pak. J. Soc. Sci. 2012, 32, 371-382.

62. Dedeoğlu, D.; Kaya, H. Energy use, exports, imports and GDP: New evidence from the OECD countries. Energy Policy 2013, 57, 469-476. [CrossRef]

63. WorldOMeter. Energy Statistics. Available online: https://www.worldometers.info/energy/china-energy/ (accessed on 3 January 2021).

64. WTO. Global Value Chain Development Report 2019: Technological Innovation, Supply Chain Trade and Workers in a Globalized World; World Bank Group: Washington, DC, USA, 2019. 
65. Li, X.; Meng, B.; Wang, Z. Recent patterns of global production and GVC participation. In Technological Innovation, Supply Chain Trade, and Workers in a Globalized World; World Trade Organization: Geneva, Switzerland, 2019. Available online: https: //www.wto.org/english/res_e/booksp_e/gvc_dev_report_2019_e_ch1.pdf (accessed on 3 April 2021).

66. Ferguson, N.; Laydon, D.; Nedjati Gilani, G.; Imai, N.; Ainslie, K.; Baguelin, M.; Ghani, A. Report 9-Impact of NonPharmaceutical Interventions (NPIs) to Reduce COVID19 Mortality and Healthcare Demand. 2020. Available online: https: //www.imperial.ac.uk/mrc-global-infectious-disease-analysis/covid-19/report-9-impact-of-npis-on-covid-19/ (accessed on 3 March 2021).

67. Hertel, T.; Tsigas, M. Structure of the GTAP model. In Global Trade Analysis: Modeling and Applications; The Press Syndicate of the University of Cambridge: New York, NY, USA, 1997; pp. 9-71.

68. Dixon, P.; Koopman, R.; Rimmer, M. The MONASH style of computable general equilibrium modeling: A framework for practical policy analysis. In Handbook of Computable General Equilibrium Modeling; Dixon, P., Jorgenson, D., Eds.; Elsevier: Oxford, UK, 2013; Volume 1, pp. 23-103, ISBN 9780444595683.

69. Burniaux, J.; Truong, T.; GTAP-E: An Energy-Environmental Version of the GTAP Model. GTAP Technical Papers, 18. 2002. Available online: https://www.gtap.agecon.purdue.edu/resources/res_display.asp?RecordID=923 (accessed on 2 January 2021).

70. Truong, T.; Kemfert, C.; Burniaux, J.; GTAP-E: An Energy-Environmental Version of the GTAP Model with Emission Trading. DIW Discussion Papers 668. 2007. Available online: https://www.gtap.agecon.purdue.edu/resources/download/3552.pdf (accessed on 17 December 2020).

71. Koopman, R.; Zhi, W.; Wei, S. Tracing value-added and double counting in gross exports. Am. Econ. Rev. 2014, 104, 459-494. [CrossRef]

72. Wang, Z.; Wei, S.; Zhu, K. Quantifying international production sharing at the bilateral and sector levels. National Bureau of Economic Research Paper 19677. 2013. Available online: https:/ /www.nber.org/papers/w19677 (accessed on 5 March 2021).

73. UNESCAP. Measuring Participation in Global Value Chains, and Developing Supportive Policies: A User Guide. 2020. Available online: https: / /www.unescap.org/resources/gvc-analysis-guide (accessed on 7 April 2021).

74. Antimiani, A.; Fusacchia, I.; Salvatici, L. An Integrated Tool for GVCs Analysis through the GTAP Model. 2018. Available online: https: / / www.gtap.agecon.purdue.edu/resources/download/8565.pdf (accessed on 6 April 2021).

75. Salvatici, L. Assessing the Impact of Trade and Other Policies on Global Value Chain (GVC) Participation, Positioning and Vertical Specialization in Agriculture and Food; Background paper for The State of Agricultural Commodity Markets (SOCO) 2020; FAO: Rome, Italy, 2020; ISBN 978-92-5-133210-8.

76. Fusacchia, I. Evaluating the impact of the US-China trade war on Euro area economies: A tale of global value chains. Ital. Econ. J. 2019, 6, 441-468. [CrossRef]

77. Fusacchia, I.; Antimiani, A.; Salvatici, L. An assessment of import tariff costs for Italian exporting firms. Econ. Politica 2021, 38, 31-56. [CrossRef]

78. UNCTAD. SDG Investment Trends Monitor. 2019. Available online: https://unctad.org/system/files/official-document/ diaemisc2019d4_en.pdf (accessed on 3 April 2021).

79. OECD. Mapping Global Value Chains, Policy Dialogue on Aid for Trade. 2012. Available online: https://www.oecd.org/dac/ aft/MappingGlobalValueChains_web_usb.pdf (accessed on 1 November 2020).

80. Fuentes, R.; Galeotti, M.; Lanza, A.; Manzano, B. COVID-19 and climate change: A tale of two global problems. Sustainability 2020, 12, 8560. [CrossRef]

81. Antonio, P.; Garcia, M. COVID-19 and the Energy Transition. Oxford Energy Forum. Issue 123. 2020. Available online: https://www.oxfordenergy.org/wpcms/wp-content/uploads/2020/07/OEF123.pdf (accessed on 10 October 2020).

82. Nyga-Łukaszewska, H.; Aruga, K. Energy prices and COVID-immunity: The case of crude oil and natural gas prices in the US and Japan. Energies 2020, 13, 6300. [CrossRef]

83. Gentile, E.; Li, G.; Mariasingham, M.J. Assessing the Impact of the United States-People's Republic of China Trade Dispute Using a Multiregional Computable General Equilibrium Model; ADB Economics Working Paper Series No. 620; Asian Development Bank: Mandaluyong City, Philippines, 2020. 